\title{
Meta-analysis of the association of IGFBP3 and IGF1 polymorphisms with susceptibility to colorectal cancer
}

\author{
W. WANG, B. Q. WU, G. B. CHEN, Y. ZHOU, Z. H. LI, J. L. ZHANG, Y. L. DING, P. ZHANG, J. Q. WANG \\ Department of General Surgery, Heping Hospital of Changzhi Medical College, Changzhi, Shaanxi, China \\ ${ }^{*}$ Correspondence: chengb1211@163.com
}

Received July 20, 2017 / Accepted November 3, 2017

\begin{abstract}
The aim of this study is to comprehensively evaluate the associations of IGFBP3 and IGF1 polymorphisms with susceptibility to colorectal cancer (CRC). We searched the English and Chinese databases and recruited case-control studies based on strict inclusion and exclusion criteria. The statistical analysis was performed by the Comprehensive Metaanalysis 2.0 (CMA 2.0) software and this initially identified 251 studies. We then recruited 10 English studies to this metaanalysis detailed review which includes 9,415 CRC patients and 14,179 healthy controls. Our results demonstrated that IGFBP3 rs $2854746 \mathrm{C}>\mathrm{G}$ polymorphism increases susceptibility to the $\mathrm{CRC}$ (allele model: $\mathrm{OR}=1.167,95 \% \mathrm{CI}=1.095 \sim 1.244$, $\mathrm{p}<0.001$ and to the dominant gene model: $\mathrm{OR}=1.226,95 \% \mathrm{CI}=1.113 \sim 1.350, \mathrm{p}<0.001)$; but $I G F B P 3 \mathrm{rs} 2854744 \mathrm{~A}>\mathrm{C}$ has no significant association with the CRC susceptibility (allele model: $\mathrm{OR}=0.970,95 \% \mathrm{CI}=0.932 \sim 1.010$, $\mathrm{p}=0.138$; dominant gene model: $\mathrm{OR}=0.995,95 \% \mathrm{CI}=0.936 \sim 1.057, \mathrm{p}=0.874)$. Also, IGF1 rs35767 C $>\mathrm{T}$ polymorphism decreases susceptibility to CRC (allele model: $\mathrm{OR}=0.785,95 \% \mathrm{CI}=0.726 \sim 0.850, \mathrm{p}<0.001$ and also the dominant model: $\mathrm{OR}=0.730,95 \%$ $\mathrm{CI}=0.661 \sim 0.806, \mathrm{p}<0.001)$. However, IGFBP3 $\mathrm{rs} 2854746 \mathrm{C}>\mathrm{G}$ is considered the susceptible CRC polymorphism and IGF1 rs $35767 \mathrm{C}>\mathrm{T}$ is $\mathrm{CRC}$ protective.
\end{abstract}

Key words: IGFBP3, IGF1, rs2854746 C>G, rs35767 C>T, polymorphism, colorectal cancer

Both colon and colorectal cancer (CRC) originate from uncontrolled cell proliferation in the gastrointestinal epithelial cell lining [1]. CRC is the third most common cancer worldwide with a global incidence exceeding 1.2 million new cases and 600,000 deaths per year, and the mortality rate is lower in men than in women $[2,3]$. The progression of CRC from benign adenoma to malignant adenocarcinoma and distant metastasis, normally takes a long time and CRC can therefore be cured if detected at an early stage However, two thirds of patients with CRCs are diagnosed at a more advanced stage because early-stage disease is mostly asymptomatic [4]. Therefore, screening and early diagnosis are more preferable to efficiently relieving the burden of disease [5]. Although the etio-pathogenesis of CRC is adventitious, epigenetic alterations of both proto-oncogenes and tumor suppressor genes are critical in tumorigenesis mechanisms [6]. As decisive factors in proliferation and apoptosis, the insulin-like growth factor (IGF) axis and functional insulin deregulation are considered the potential mechanisms explaining colorectal carcinogenesis [7].
IGF1, a protein encoded by the IGF1 gene located on chromosome 12 [8], exerts biological effects through activating the insulin-like growth factor type 1 receptor (IGF-1R), but the relationship between expressions of IGF1 and IGF-1R and CRC clinical-pathological factors remains unclear [9]. IGF1 and members of the IGF-binding protein family (IGFBPs) are essential for cell cycle regulation [10].

IGF1, as a peptide growth factor, can improve cell proliferation and restrain apoptosis and it is also regulated by the insulin-like growth factor binding protein IGFBP3 [11]. Extant studies show that IGF1, IGFBP3 and insulin significantly influence the pathogenesis of colon cancer through regulating cell growth and proliferation $[12,13]$. Moreover, the insulin level, IGF1 level, IGF1/IGFBP3 ratio and reduction of IGFBP3 may be related to the initiation of CRC, but not to the progression and outcome of the disease [12]. The IGF1 gene comprises a highly conservative sequence with 6 exons, which give rise to heterogeneous mRNA transcripts by combining multiple transcription initiation sites and alternative splicing [14]. The IGFBP3 gene, on human chromo- 
some 7 , is integrated in four protein-coding exons and a 5 th exon in the 3' untranslated region [15]. IGFBP3 acts as a hypoxia-inducible gene and it regulates a series of cellular processes, including senescence, cell proliferation, epithelialmesenchymal transition and apoptosis [16]. The activities of $I G F-1$ are controlled by interaction of several high-affinity IGFBPs; especially IGFBP3 which directly carries IGF-1 to target tissues, prevents it from proteolytic degradation and regulates its interaction with IGF-1R. Its expression is negatively related to $I G F-1$ expression $[17,18]$. IGF1 and IGFBP3 gene polymorphisms may affect circulation levels of IGF1 and IGFBP3, and high IGF1 level but low IGFBP3 level contributes to increased cancer risk $[7,19]$. In addition, IGFBP3 has an effect in its own IGF-independent apoptosis through mediation of a specific cell surface receptor [20]. These findings suggest that genetic variations in the IGF1 and the IGFBP3 genes play important roles in colorectal tumourigenesis $[21,22]$. However, previous studies indicated that polymorphic variations in IGF1 and IGFBP-3 genes may have no association with the CRC risk $[11,23,24]$. This present study therefore investigates the relationship of IGF1 and IGFBP3 polymorphisms with colorectal cancer susceptibility.

\section{Materials and methods}

Search methods. We searched PubMed (1996 Aug. 2017), Cochrane Library (CEN-TRAL, 2017), Ovid (1948 Aug. 2017), Embase (1966 Aug. 2017), CNKI(1994 Aug. 2017) and Wanfang database (1986 Aug. 2017), following search terms: "Colorectal Neoplasms" or "Colorectal Neoplasm" or "Colorectal Tumor" or "Colorectal Carcinoma" or "Colorectal Cancer" or "Colorectal Cancer" and "InsulinLike Growth Factor Binding Protein 3" or "IGFBP-3" or "IGF-Binding Protein 3" or "IGF Binding Protein 3" or "Protein 3, IGF-Binding" and "Polymorphism, Genetic" or "Genetic Polymorphism" or "Polymorphism (Genetics)"and "IGF1 protein, human". Then we manually searched the reference lists of the retrieved articles and reviews in other relevant studies.

Inclusion and exclusion criteria. Studies were based on the following inclusion criteria: (1) all studies had to be casecontrolled, with participants divided into CRC and non-CRC groups; (2) the research topic was associated with the IGFBP3 and IGF1 gene polymorphism and susceptibility to CRC; (3) the outcome index ensured the studies provided the information for IGFBP3 rs2854746 C>G, rs2854744 $\mathrm{A}>\mathrm{C}$ and IGF1 rs35767 C>T. The exclusion criteria were: (1) summaries and abstracts only; (2) duplicated studies and (3) insufficient statistics. Inclusion was discussed until consensus was reached.

Data extraction. Two independent investigators extracted the data from eligible studies. Two authors reviewed all articles that suited inclusion criteria. The information was collected as follows: surname and initials of the first author, year of publication, source country, language of publication, cases, demographic variables of the subjects, study designs, detective methods, single nucleotide polymorphisms (SNPs), and genotype frequencies; disagreement was solved by a third investigator.

Statistical analysis. Data analysis was performed by Comprehensive Meta-analysis 2.0 (CMA 2.0; Biostatic Inc., Englewood, New Jersey, USA). Hardy-Weinberg equilibrium (HWE) was assessed by $\chi^{2}$ test in the control group of each study. Odds ratio (OR) and 95\% confidence intervals (95\% CI) for CRC were calculated by comparing differences in allele and genotype frequency of TLR4 rs4986790A $>\mathrm{G}$ and rs4986791 C>T polymorphisms. The significance of overall effect sizes was evaluated by $\mathrm{Z}$ test [25]. Forest plots were applied to reflect the comparisons of ORs and 95\% CI between the case study and controls. The heterogeneity between included trials was estimated by the Cochran's Q-statistic ( $<<0.05$ was considered significant) and also the $I^{2}$ test ( $0 \%$, no heterogeneity; $100 \%$, maximal heterogeneity) $[25,26]$. The fixed-effect model was applied to calculate parameters when heterogeneity was not an issue; otherwise the random effect model was used [27]. Metaregression univariate analysis was applied to identify potential sources of heterogeneity and the Monte Carlo simulation for further confirmation [28-30]. Sensitivity analysis evaluated whether the removal of a single study would influence the overall outcome. The Egger's linear regression test, funnel plot and classic fail-safe- $\mathrm{N}$ analyzed publication bias [31-33]. All tests were two-sided, and $\mathrm{p}<0.05$ indicated statistical significance.

\section{Results}

Selection of eligible studies. Our search identified 251 relative studies. After excluding duplicates $(n=32)$, letters, reviews and meta-analysis $(\mathrm{n}=48)$, non-human studies $(n=21)$ and studies irrelevant to research topics $(n=70)$, we reviewed 80 full-text articles. Through detailed evaluation, we further excluded 67 studies (14 uncontrolled case studies, 18 studies irrelevant to IGFBP3 or IGF1, 35 studies irrelevant to CRC) and 3 studies with irrelevant data. Finally, 10 eligible case-control studies from 2005 2012 [7, 13, 22, 23, 34-39] were incorporated in the study. They comprised 9,415 CRC patients and 14,179 healthy controls, and the sample size in each study ranged from 414 to 5,271 . The flow chart of selection of eligible studies is shown in Figure 1. Eight studies were conducted in Caucasians and 2 in Asians. Polymerase chain reaction with the restriction fragment length polymorphism (PCR RFLP) and TaqMan assay were applied for detection of SNP. In most eligible studies, the genotype distributions of studied loci were in accordance with the HWE (all p>0.05); except two studies with IGF1 rs35767 C > T $[23,36]$ and one study with IGFBP3 rs2854744 $\mathrm{A}>\mathrm{C}$ [34]. The IGFBP3 and IGF1 gene loci-related information is summarized in Table 1 . 


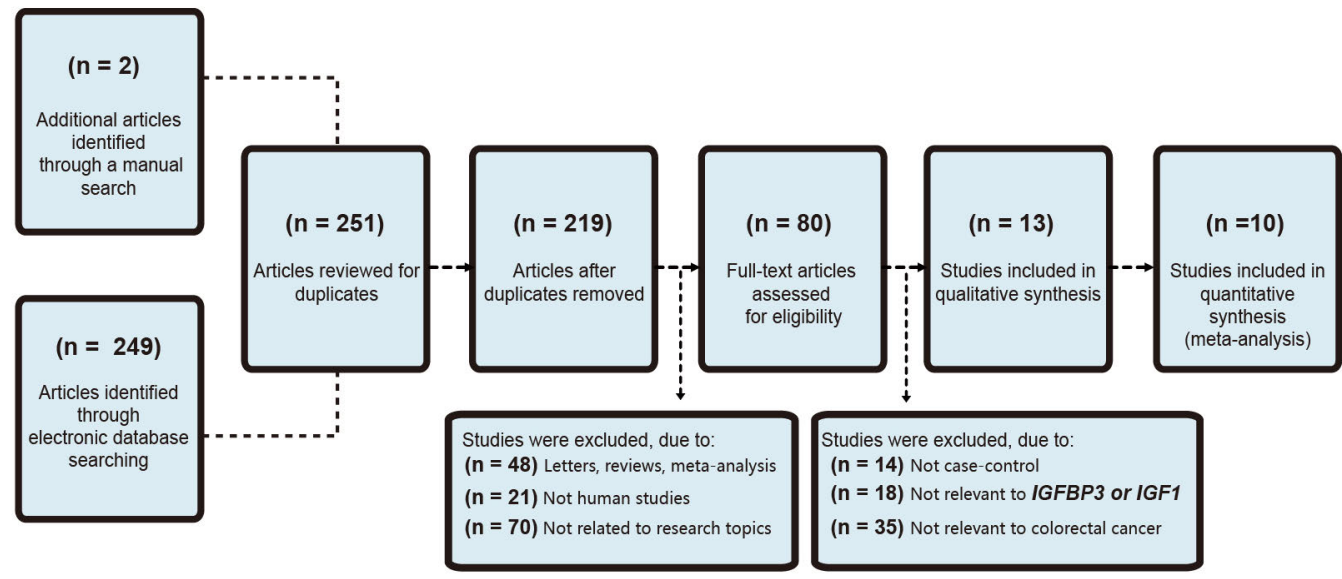

Identification

Figure 1. Flow chart of selected eligible studies. We searched 251 relative studies ( 249 studies from electronic databases and 2 from manual search). After excluding duplicates $(n=32)$, letters, reviews or meta-analysis $(n=48)$, non-human studies $(n=21)$, unrelated to research topics $(n=70)$, 80 fulltext articles remained. Through further reading and evaluation, we rejected 67 studies (14 studies for not being case-controlled, 18 for irrelevance to IGFBP3 or IGF1 and 35 studies for irrelevance to CRC). A further 3 studies had irrelevant data so finally there were 10 eligible case-control studies from 2005-2012 included in our study $[7,13,22,23,34-39]$.

Table 1. The IGFBP3 and IGF1 variants that have ever been reported in colorectal cancer and characteristics of studies included in this meta-analysis.

\begin{tabular}{|c|c|c|c|c|c|c|c|c|c|c|c|c|}
\hline SNP & thor & ear & $y$ & y & Genes & $\begin{array}{l}\text { Study } \\
\text { design }\end{array}$ & $\begin{array}{l}\text { Source of } \\
\text { controls }\end{array}$ & $\begin{array}{l}\text { Genotype } \\
\text { method }\end{array}$ & $\begin{array}{c}\text { Sample size } \\
\text { (case/control) }\end{array}$ & $\begin{array}{c}\text { Adjusted } \\
\text { factors }\end{array}$ & HWE & $\begin{array}{l}\text { CASP } \\
\text { score }\end{array}$ \\
\hline 3) & lber & 2 & USA & ians & P3 & ase-Control & $\mathrm{PB}$ & Man & 87 & 5,6 & 100 & 10 \\
\hline rs2854746 (C>G) & 3] & 10 & $a$ & ucasians & BP3 & se-Control & $\mathrm{PB}$ & Man & 95 & $, 4,5,6$ & 450 & 9 \\
\hline rs2854746 ( & Xiang H [22] & 2003 & ha & Asians & IGFBP3 & Case-Control & $\mathrm{PB}$ & TaqMan & $02 / 212$ & $1,2,3,4,5,6$ & 0.717 & 8 \\
\hline rs2854746 (C>G) & Pechlivanis S & 2007 & (9) & Caucasians & IGFBP3 & - ast-coritior & 10 & TaqMan & 年 & $1,2,3,4,5,6$ & 0.072 & 9 \\
\hline rs2854746 (C>G) & Morimoto Ll & 2005 & - & Caucasians & IGFBP3 & Case-Control & 12 & PCR-RFLP & & $1,2,3,4,5,6$ & 0.098 & 8 \\
\hline s2854744 (A>C) & Ollber & 2012 & 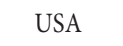 & casians & P3 & Case-Control & PB & TaqMan & & $1,2,3,4,5,6$ & 0.100 & 10 \\
\hline s2854744 (A>C) & КекU & 2012 & 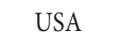 & Caucasians & P3 & Case-Control & D & TaqMan & 10 & $1,2,3,4,5,6$ & 0.253 & 3 \\
\hline rs2854744 $(\mathrm{A}>\mathrm{C})$ & Feik E [13] & 2010 & Austria & Caucasians & IGFBP3 & Case-Control & $\mathrm{PB}$ & TaqMan & $178 / 1795$ & $1,2,3,4,5,6$ & 0.450 & 9 \\
\hline rs2854744 (A>C) & Xiang H [22] & 2009 & China & Asians & IGFBP3 & Case-Control & $\mathrm{PD}$ & TaqMan & $202 / 212$ & $1,2,3,4,5,6$ & 0.717 & 8 \\
\hline rs2854744 (A>C) & Pechlivanis S [23] & 2007 & Germany & Caucasians & IGFBP3 & Case-Control & $\mathrm{PB}$ & TaqMan & $661 / 607$ & $1,2,3,4,5,6$ & 0.392 & 9 \\
\hline rs2854744 (A>C) & Slattery ML [38] & 2006 & USA & Caucasians & IGFBP3 & Case-Control & PB & PCR-RFLP & $2371 / 2972$ & $1,2,3,4,5,6$ & 0.844 & 8 \\
\hline rs2854744 (A>C) & Samowitz WS [37] & 2006 & USA & Caucasians & IGFBP3 & Case-Control & $\mathrm{PB}$ & PCR-RFLP & $1788 / 1981$ & $1,2,3,4,5,6$ & 0.325 & 9 \\
\hline rs2854744 (A>C) & Wong HL [39] & 2005 & Singapore & Asians & IGFBP3 & Case-Control & PB & TaqMan & $290 / 873$ & $1,2,3,4,5,6$ & 0.112 & 8 \\
\hline rs2854744 (A>C) & Le Marchand L [34] & 2005 & USA & Caucasians & IGFBP3 & Case-Control & PB & PCR-RFLP & $2298 / 2749$ & $1,2,3,4,5,6$ & 0.817 & 9 \\
\hline rs35767 (C>T) & Ollberding NJ [36] & 2012 & USA & Caucasians & IGF1 & Case-Control & $\mathrm{PB}$ & TaqMan & $1954 / 2587$ & $1,2,3,4,5,6$ & 0.100 & 10 \\
\hline rs35767 (C>T) & Feik E [13] & 2010 & Austria & Caucasians & IGF1 & Case-Control & $\mathrm{PB}$ & TaqMan & $178 / 1795$ & $1,2,3,4,5,6$ & 0.450 & 9 \\
\hline rs35767 $(\mathrm{C}>\mathrm{T})$ & Pechlivanis S [23] & 2007 & Germany & Caucasians & IGF1 & Case-Control & $\mathrm{PB}$ & TaqMan & $661 / 607$ & $1,2,3,4,5,6$ & 0.392 & 9 \\
\hline
\end{tabular}

Notes: CASP, critical appraisal skill program; HWE, Hardy-Weinberg equilibrium; PB, population based; 1, Year; 2, Country; 3, Ethnicity; 4, Genotype method; 5, SNP; 6, Sample size.

Associations between IGFBP3 gene rs2854746 C>G polymorphism and CRC susceptibility. Five studies demonstrated the associations of IGFBP3 gene rs 2854746 $\mathrm{C}>\mathrm{G}$ with susceptibility to CRC. The random effect model was adopted because of observed heterogeneity in the allele model and dominant gene model $(\mathrm{p}<0.05)$. Results demonstrated that IGFBP3 gene rs2854746 C>G polymorphism increases susceptibility to CRC (allele model: $\mathrm{OR}=1.167,95 \%$ $\mathrm{CI}=1.095 \sim 1.244, \mathrm{p}<0.001$; dominant gene model: $\mathrm{OR}=1.226$, 95\% $\mathrm{CI}=1.113 \sim 1.350, \mathrm{p}<0.001$ ) (Figures $2 \mathrm{~A}, 2 \mathrm{~B}$, Table 2). 
The subgroup analyses based on ethnicity determined that IGFBP3 gene rs $2854746 \mathrm{C}>\mathrm{G}$ polymorphism may increase the CRC susceptibility among both Asians and Caucasians (Asians: allele model: $\mathrm{OR}=1.448,95 \% \mathrm{CI}=1.058 \sim 1.982$, $\mathrm{p}=0.021$; dominant model: $\mathrm{OR}=1.554,95 \% \mathrm{CI}=1.052 \sim 2.296$, $\mathrm{p}=0.027$; Caucasians: allele model: $\mathrm{OR}=1.156,95 \%$ $\mathrm{CI}=1.083 \sim 1.234, \mathrm{p}<0.001$; allele model: $\mathrm{OR}=1.207,95 \%$ $\mathrm{CI}=1.092 \sim 1.334, \mathrm{p}<0.001$ ) (Figures $3 \mathrm{~A}, \mathrm{~B})$.

Table 2. Comparisons of genotype and allele frequencies between the case and the control groups.

\begin{tabular}{|c|c|c|c|c|c|c|c|c|c|c|}
\hline \multirow{2}{*}{ SNP } & & \multicolumn{3}{|c|}{ rs2854746 C>G } & \multicolumn{3}{|c|}{ rs2854744 A>C } & \multicolumn{3}{|c|}{ rs35767 C>T } \\
\hline & & OR & 95\%CI & p-value & OR & $95 \% \mathrm{CI}$ & p-value & OR & $95 \% \mathrm{CI}$ & p-value \\
\hline M allele vs. W allele (Allele model) & Overall & 1.167 & $1.095 \sim 1.244$ & $<0.001$ & 0.97 & $0.932 \sim 1.010$ & 0.138 & 0.785 & $0.726 \sim 0.850$ & $<0.001$ \\
\hline WM + MM vs. WW (Dominant model) & Overall & 1.226 & $1.113 \sim 1.350$ & $<0.001$ & 0.995 & $0.936 \sim 1.057$ & 0.874 & 0.73 & $0.661 \sim 0.806$ & $<0.001$ \\
\hline MM vs. WW (Homozygous model) & Overall & 1.3 & $1.150 \sim 1.470$ & $<0.001$ & 0.957 & $0.880 \sim 1.036$ & 0.227 & 0.721 & $0.594 \sim 0.876$ & 0.001 \\
\hline MM vs. WM (Heterozygous model) & Overall & 0.891 & $0.795 \sim 0.999$ & 0.048 & 0.963 & $0.816 \sim 1.136$ & 0.656 & 1.155 & $0.947 \sim 1.408$ & 0.115 \\
\hline MM vs. WW + WM (Recessive model) & Overall & 1.191 & $1.072 \sim 1.324$ & $<0.001$ & 0.927 & $0.866 \sim 1.126$ & 0.472 & 0.778 & $0.645 \sim 0.939$ & 0.009 \\
\hline
\end{tabular}

Notes: OR, odds ratio.

A

Author
Ollberding NJ (2012)
Feik E (2010)
Xiang H (2009)
Pechlivanis S (2007)
Morimoto LM (2005)
overall

rs2854746 C>G: G allele vs C allele

Odds ratio and $95 \% \mathrm{Cl}$

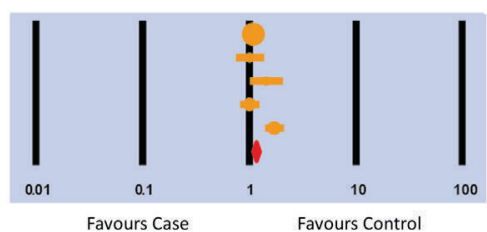

Heterogeneity test $\left(I^{2}=87.117 \%, P<0.001\right)$
2 test
Rand $=4.732$, $P(C 0.001)$

C

rs2854744 A>C: C allele vs A allele

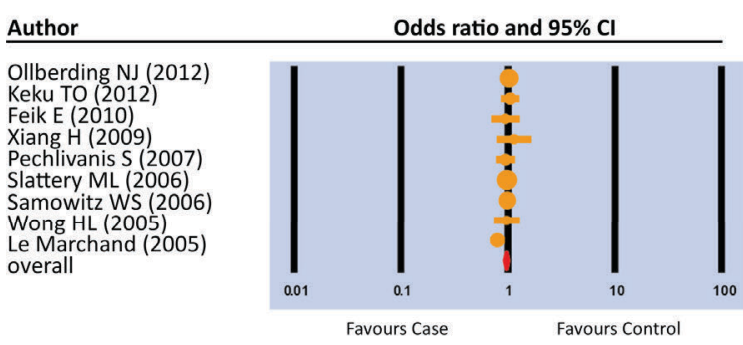

Heterogeneity test $\left(I^{2}=44.218 \%, P=0.073\right)$
L test $2=-1.482, P=0.138)$

\section{E}

rs35767 C>T: T allele vs C allele

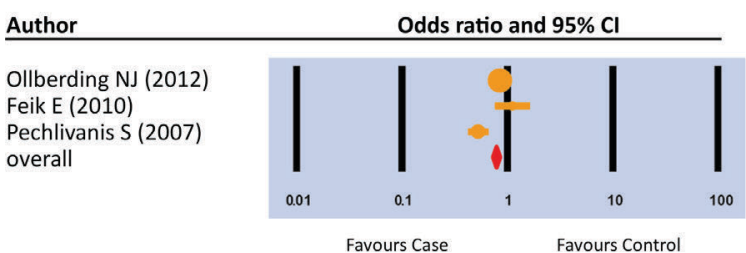

Heterogeneity test $\left(1^{2}=92.275 \%, \mathrm{P}<0.001\right)$
Z test $(2=-6.012, \mathrm{P}=0.001)$
Random effect analysis
B

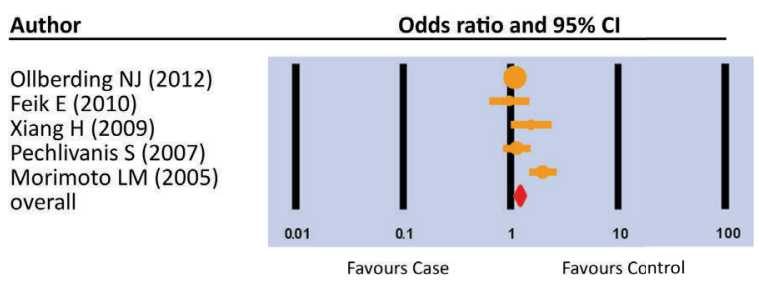

Heterogeneity test $\left(I^{2}=80,802 \%, P<0.001\right)$
Z test $(2=4.126, P<0.001)$
Rand

D

rs2854744 $A>C$ : $A C+C C$ vs $A A$

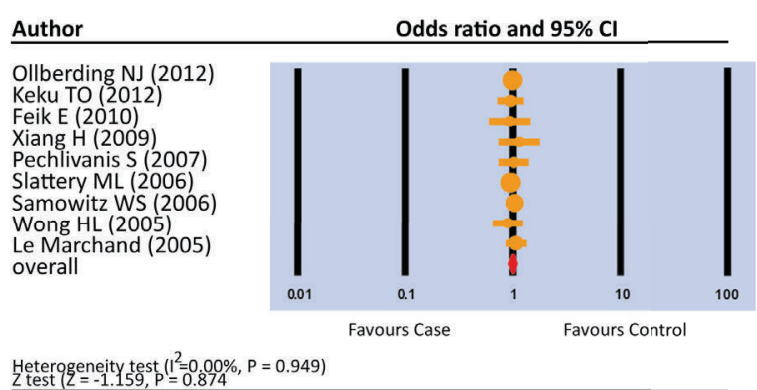

$\mathbf{F}$

rs35767 C>T: CT+TT vs CC

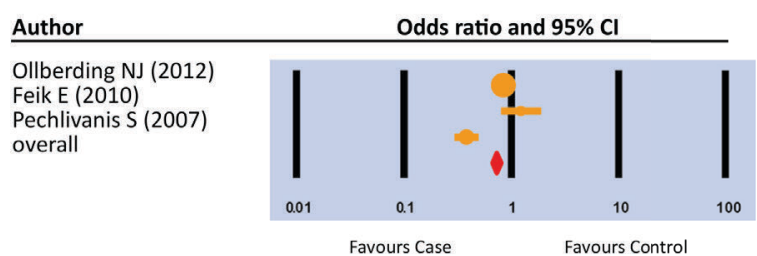

Heterggeneity test $\left(1^{2}=95.862 \%, P<0.001\right)$
2 test
Rando $=-6.94, \quad=0.001)$

Figure 2. Forest plots for the association of IGFBP3 gene rs2854746 C>G and rs2854744 A>C polymorphism and IGF1 gene rs35767 C>T polymorphism with CRC susceptibility. Under allele mode and dominant model, IGFBP3 gene rs2854746 C>G and IGF1 gene rs35767 C $>$ T polymorphism could increase the CRC susceptibility (all p $<0.05$, shown in A, B, E, F), while IGFBP3 gene rs 2854744 A $>C$ polymorphism had no significant influence on the susceptibility to CRC (all p>0.05, shown in C, D). The complete set of statistical data is in Supplementary Figure 1 . 

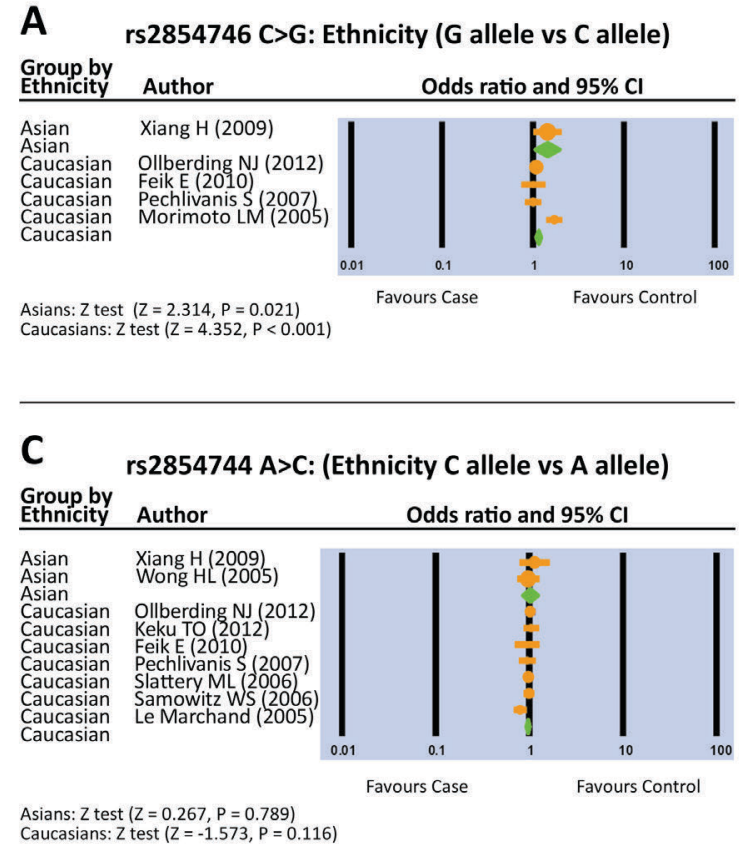

B

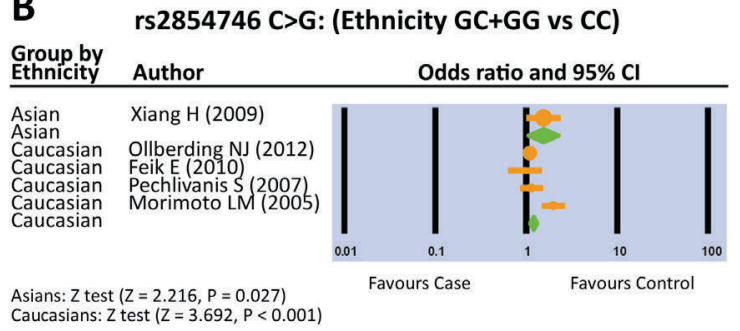

D

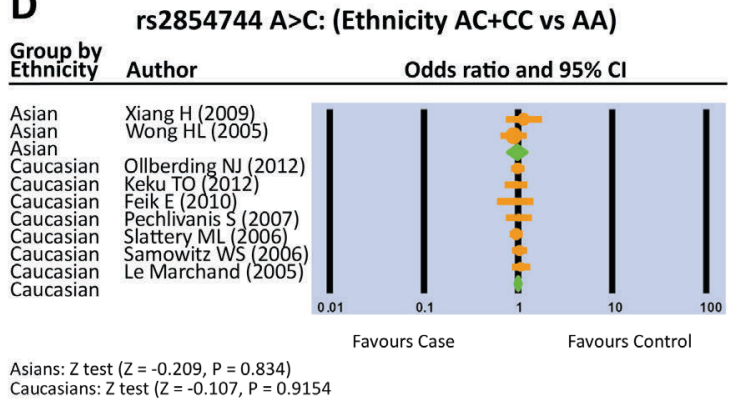

Figure 3. Subgroup analysis by ethnicity for the association of IGFBP3 gene rs2854746 C $>$ G and rs2854744 A $>$ C polymorphism with CRC susceptibility. Under allele mode and dominant model, IGFBP3 gene rs $2854746 \mathrm{C}>\mathrm{G}$ polymorphism may increase the CRC susceptibility in both Asians and Caucasians (all p $<0.05$, shown in A, B), while IGFBP3 gene rs2854744 A $>$ C polymorphism was not related to CRC susceptibility in either Asians or Caucasians (all p >0.05, shown in C, D). The complete set of statistical data is in Supplementary Figure 2.

Associations between IGFBP3 gene rs2854744 A>C polymorphism and CRC susceptibility

Nine studies demonstrated association of IGFBP3 gene rs2854744 A>C with CRC susceptibility. The fixed effect model was adopted because no heterogeneity was observed in the allele model or dominant gene model $(\mathrm{p}>0.05)$. The results demonstrated that IGFBP3 gene rs2854744 $\mathrm{A}>\mathrm{C}$ polymorphism had no significant influence on susceptibility to CRC (allele model: OR $=0.970,95 \%$ $\mathrm{CI}=0.932 \sim 1.010, \mathrm{p}=0.138$; dominant model: $\mathrm{OR}=0.995$, 95\% CI=0.936 1.057, $\mathrm{p}=0.874$ ) (Figures 2C, 2D, Table 2). The subgroup analyses based on ethnicity established that IGFBP3 gene rs2854744 A $>$ C polymorphism was unrelated to CRC susceptibility in both Caucasian and Asian subjects ( $\mathrm{p}>0.05$ ) (Figures 3C, D).

Associations between IGF1 gene rs35767 C $>$ T polymorphism and CRC susceptibility. Three studies demonstrated the associations of IGF1 gene rs35767 C>T polymorphism with susceptibility to CRC. The random effect model was adopted because of observed heterogeneity in the allele and dominant gene models $(\mathrm{p}<0.05)$. The results demonstrated that IGF1 gene rs35767 $\mathrm{C}>\mathrm{T}$ polymorphism decreased the CRC susceptibility (allele model: $\mathrm{OR}=0.785,95 \%$ $\mathrm{CI}=0.726 \sim 0.850, \mathrm{p}<0.001$ and dominant model: $\mathrm{OR}=0.730$, $95 \% \mathrm{CI}=0.661 \sim 0.806, \mathrm{p}<0.001$ ) (Figures $2 \mathrm{E}, 2 \mathrm{~F}$, Table 2). No subgroup analysis was made on ethnicity because eligible studies only included Caucasians.

Sensitivity analysis and publication bias. Sensitivity analysis indicated that the IGFBP3 gene rs2854746 $\mathrm{C}>\mathrm{G}$, rs2854744 $\mathrm{A}>\mathrm{C}$ and IGF1gene rs35767 $\mathrm{C}>\mathrm{T}$ showed no significant influences on pooled ORs of CRC (Figure 4). Publication year, country, ethnicity, SNPs, genotype methods and sample size were not the main sources of heterogeneity or crucial factors in the overall size of the effect. This was indicated by the univariate meta-regression analysis (all $\mathrm{p}>0.05$ ) (Figure 5). The shape of funnel plots of genotype differences in IGFBP3 gene rs2854746 C > G, rs2854744 A $>C$ and IGF1 gene rs35767 C>T did not show any evidence of symmetry and the statistical results did not show publication bias. No existence of obvious publication bias was found by Classic fail-safe $\mathrm{N}$ and Egger's linear regression test (all $\mathrm{p}>0.05$ ) (Figure 6).

\section{Discussion}

We conducted this meta-analysis to investigate associations of IGFBP3 and IGF1 polymorphisms with susceptibility to colorectal cancer; and we finally concluded that IGFBP3 rs2854746 C>G and IGF1 rs35767 C>T correlated with CRC. Specifically, IGFBP3 rs2854746 C>G is most likely 
A

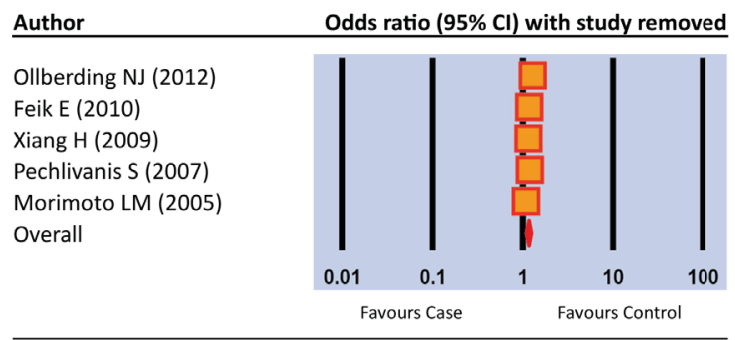

C

rs2854744 A>C: C allele vs A allele

Author Odds ratio (95\% Cl) with study removed

Ollberding NJ (2012) Keku TO (2012) Feik E (2010) Xiang H (2009) Pechlivanis S (2007) Slattery ML (2006) Samowitz WS (2006) Wong HL (2005) Le Marchand (2005) Overall

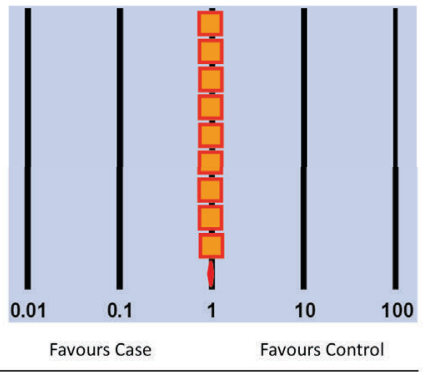

E

rs35767 C>T: T allele vs C allele

Author Odds ratio $(95 \% \mathrm{Cl})$ with study removed

Ollberding NJ (2012) Feik E (2010) Pechlivanis S (2007) Overall

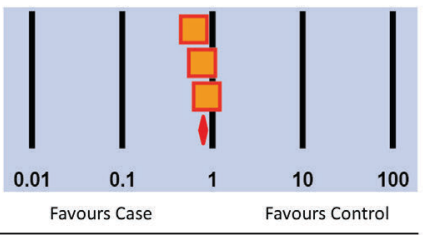

B

rs2854746 C>G: CG+GG vs CC

Author

Ollberding NJ (2012)

Feik E (2010)

Xiang $\mathrm{H}$ (2009)

Pechlivanis S (2007)

Morimoto LM (2005)

Overall

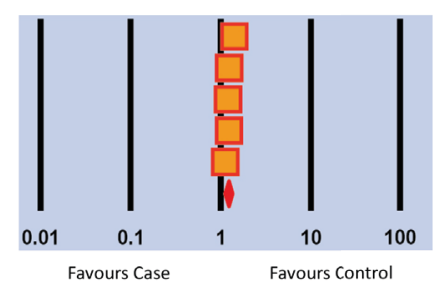

D

Author

rs2854744 $A>C: A C+C C$ vs $A A$

Ollberding NJ (2012)

Keku TO (2012)

Feik E (2010)

Xiang $\mathrm{H}$ (2009)

Pechlivanis S (2007)

Slattery ML (2006)

Samowitz WS (2006)

Wong HL (2005)

Le Marchand (2005)

Overall

Odds ratio $(95 \% \mathrm{Cl})$ with study removed

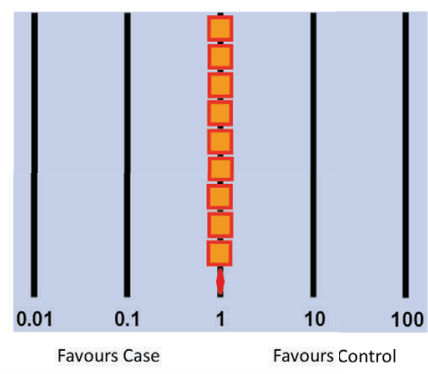

F

Author

rs35767 C>T: CT+TT vs CC Odds ratio $(95 \% \mathrm{Cl})$ with study removed

Ollberding NJ (2012)

Feik E (2010)

Pechlivanis S (2007)

Overall

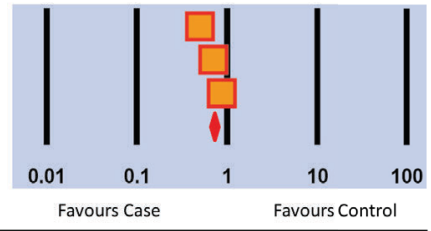

Figure 4. Sensitivity analysis for the association of IGFBP3 gene rs2854746 C > G and rs2854744 $\mathrm{A}>\mathrm{C}$ polymorphism and IGF1 gene rs35767 C $>\mathrm{T}$ polymorphism with CRC susceptibility. Under allele mode and dominant model, the IGFBP3 gene rs2854746 C > G, rs2854744 A>C and IGF1 gene rs35767 C $>$ T showed no significant influences on pooled ORs of CRC. The complete set of statistical data is shown in Supplementary Figure 3.

the susceptible CRC polymorphism and IGF1 rs35767 C>T may be the protective CRC polymorphism.

Our overall findings demonstrated that IGF1 rs35767 C $>\mathrm{T}$ polymorphism decreased the susceptibility to CRC while IGFBP3 rs2854746 C>G polymorphism increased CRC susceptibility. The IGF family is expected to have an essential role in regulating cell proliferation, apoptosis, and transformation [11]. IGF1, widely regarded as a circulating growth factor, is normally produced by the liver and participates in mediating body growth through growth hormone effects [40], but it is fatal for the normal development and growth of cell maintenance and homeostasis [9].

A previous study also showed that IGF1 is expressed locally in many tissues, including skeletal muscle, thus implying that paracrine and autocrine effects of local IGF1 are a major mechanism controlling tissue growth [41]. Moreover, IGF1, a peptide growth factor, stimulates cell division and inhibits apoptosis and its abnormal expression could therefore contribute to cancer development and metastasis; including in CRC $[11,42]$.

To regulate cellular growth and differentiation, the IGF system and apoptosis circulate IGF family growth factors which bind IGFBP proteins and IGF receptors 1 and 2 cell surface receptors [36]. IGFBP3 has inherent anti-proliferative and pro-apoptotic ability, and the circulating IGF1 and IGFBP3 concentrations and down-stream signaling molecules may relate to CRC [43]. It has been reported that high levels of circulating IGF1 and/or low levels of IGFBP3 are associated with elevated CRC risk [44].

In addition, IGFBP-3 rs 2854744 was recently reported to be related to IGFBP- 3 concentration, and its $\mathrm{C}$ allele may lower IGFBP-3 concentration [11]. This has attracted great atten- 
A

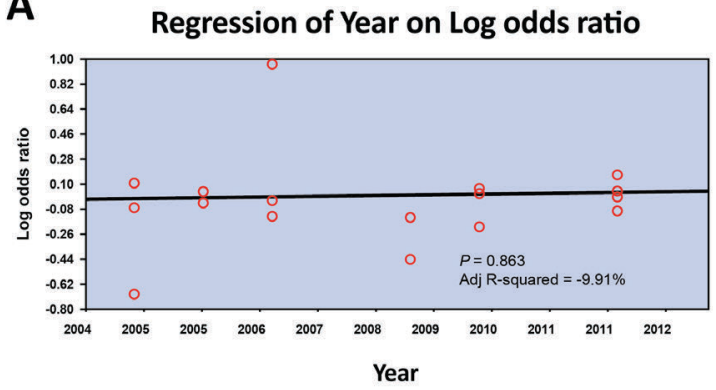

C

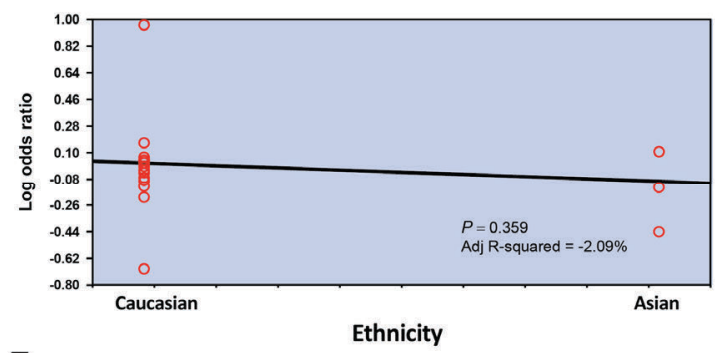

E

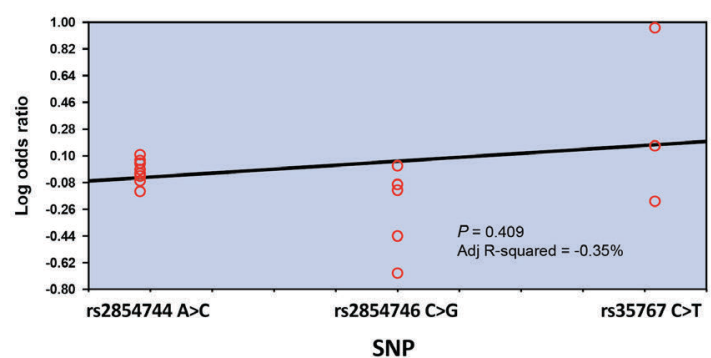

B

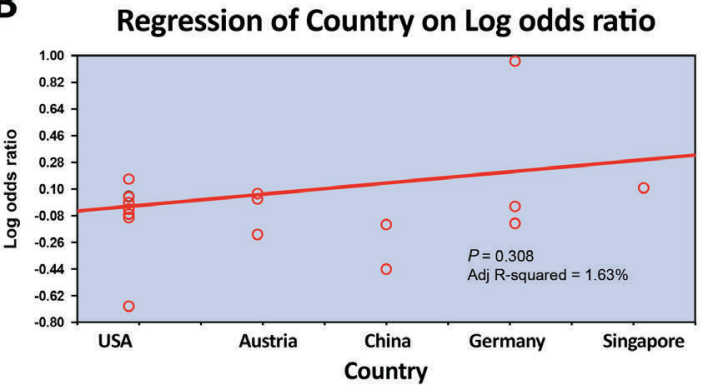

D Regression of Genotyp method on Log odds ratio

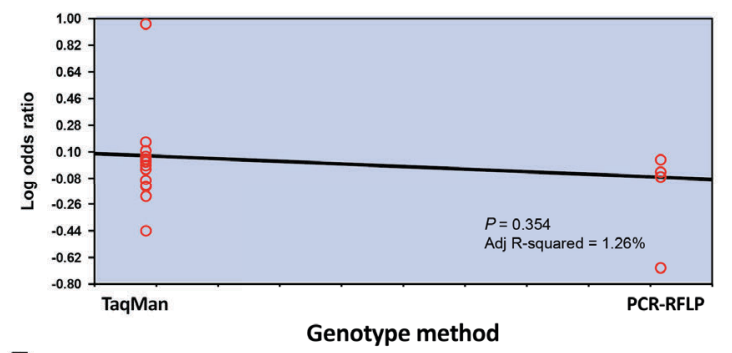

$\mathbf{F}$

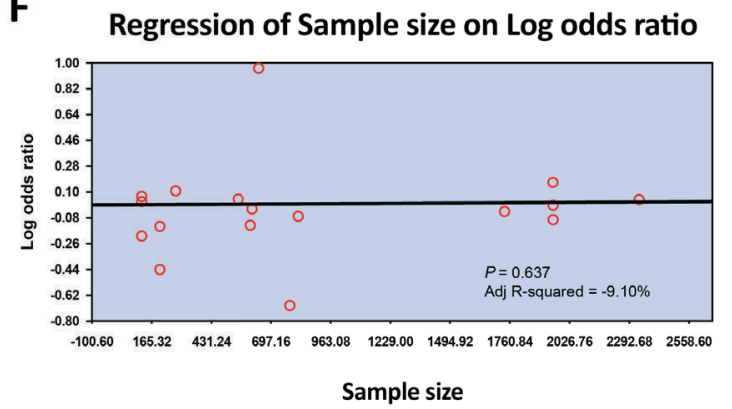

Figure 5. Meta-regression analysis for the association of IGFBP3 gene rs2854746 C>G and rs 2854744 A $>$ C polymorphism and IGF1 gene rs35767 C>T polymorphism with CRC susceptibility. Publication year, country, ethnicity, SNPs, genotype methods and sample size were not the main sources of heterogeneity or crucial factors in the overall size effect; as indicated in the univariate meta-regression analysis (all p $>0.05$ ).

tion. IGFBP-3 can modulate the mitogenic and metabolic effects of IGFs encoded by the IGFBP-3 gene [16]. The IGFBP3 circulating level is significantly influenced by the IGFBP3 gene rs2854746 C>G located at position -202 (rs2854744, A.C) as a transcription start-site affecting promoter activity and rs35767 $\mathrm{C}>\mathrm{T}$ is regarded as a non-synonymous substitution with the Gly32Ala (rs2854746, G.C) site providing high affinity IGF1 binding [45]. Rare variant alleles of the functional G2133C, rs2854746 polymorphisms have consistently been associated with decreased circulating levels of IGFBP3, thus suggesting that the exon 1 G2133C missense variant in IGFBP3 is critical in silencing its expression $[7,46]$. This indicates that the IGFBP3rs2854746 SNP increases CRC risk by inhibiting the circulating level of IGFBP3. Previous studies support our findings by demonstrating that the exon 1 G2133C missense variant in IGFBP3 may be a susceptibility factor for CRC in an allele dose-responsive manner [22, 34]. IGFBP3 is the binding protein for IGF1 that decreases cancer risk by mediating the bioavailability of freely circulating IGF1. This stimulates apoptosis and reduces cell proliferation in an IGF1-independent manner [36].

There are several limitations in our meta-analysis. We had no access to original data from included studies and this limited further research into potential interactions. The fact that only one rs2854746 study for Asian ethnicity was included may cause bias. Moreover, differing language in published studies could also cause bias in the overall estimates.

Subgroup analyses based on ethnicity were then conducted to consider the influence of ethnicity on the associations of IGFBP3 gene rs2854746 C>G and IGF1 gene rs35767 $\mathrm{C}>\mathrm{T}$ polymorphisms with CRC. These ethnicity-stratified analyses revealed the influence of ethnicity on associations 
Figure 6. Funnel plot of publication bias in the association of IGFBP3 gene rs2854746 $C>G$ and rs2854744 $\mathrm{A}>\mathrm{C}$ polymorphism and IGF1 gene rs35767 C $>\mathrm{T}$ polymorphism with $\mathrm{CRC}$ susceptibility. The shape of funnel plots of genotype differences in IGFBP3 gene rs2854746 C > G, rs2854744 $A>C$ and IGF1 gene rs35767 $\mathrm{C}>\mathrm{T}$ did not show any evidence of symmetry and the statistical results did not show publication bias. No existence of obvious publication bias was found by Classic fail-safe $\mathrm{N}$ and Egger's linear regression test (all $p>0.05$ ). The complete set of statistical data is in Supplementary Figure 4.
A

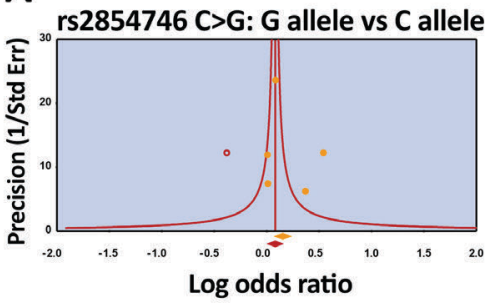

C

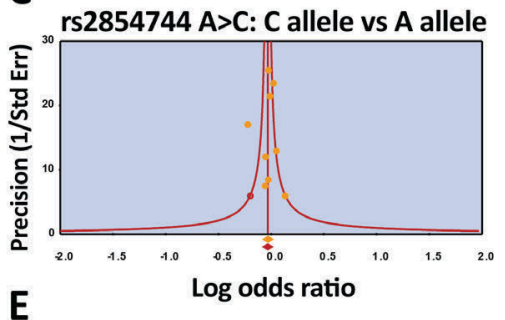

E

rs35767 C > T: T allele vs C allele

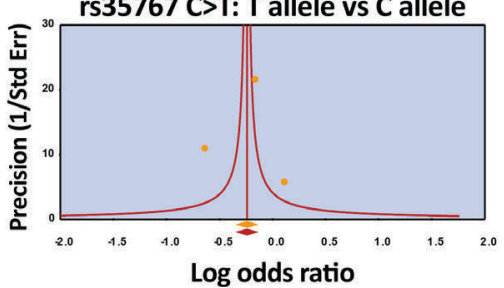

B

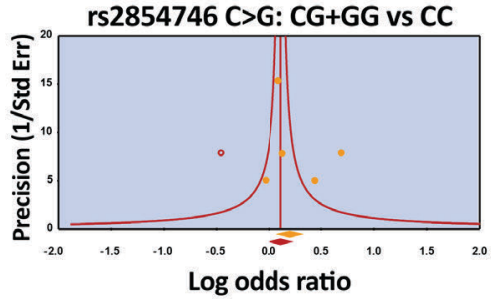

D

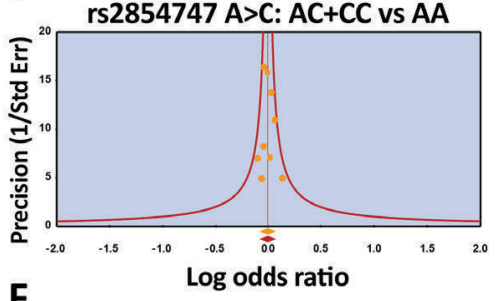

rs35767 C>T: ct+TT vs CC

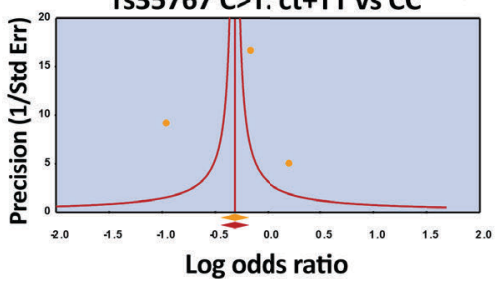

between IGFBP3 gene and CRC risk. The subgroup analysis suggested that IGFBP3 gene rs2854746 C>G polymorphism increased susceptibility to CRC in both Asians and Caucasians. Moreover, no significant associations between IGFBP3 gene rs2854744 $\mathrm{A}>\mathrm{C}$ polymorphism and CRC susceptibility were observed in either Asians or Caucasians.

In conclusion, our study demonstrates that IGFBP3 rs $2854746 \mathrm{C}>\mathrm{G}$ is most likely the susceptible CRC polymorphism and IGF1 rs35767 C>T is the protective polymorphism in colorectal cancer.

Supplementary information is available in the online version of the paper.

Acknowledgments: We are grateful to our instructors for their valuable advice.

\section{References}

[1] CRNCEC I, PATHRIA P, SVINKA J, EFERL R. Induction of colorectal cancer in mice and histomorphometric evaluation of tumors. Methods Mol Biol 2015; 1267: 145-164. https:// doi.org/10.1007/978-1-4939-2297-0_7

[2] VAN EMBURGH BO, SARTORE-BIANCHI A, DI NICOLANTONIO F, SIENA S, BARDELLI A. Acquired resistance to EGFR-targeted therapies in colorectal cancer. Mol Oncol 2014; 8: 1084-1094. https://doi.org/10.1016/j. molonc.2014.05.003
[3] MOHELNIKOVA-DUCHONOVA B, MELICHAR B, SOUCEK P. FOLFOX/FOLFIRI pharmacogenetics: the call for a personalized approach in colorectal cancer therapy. World J Gastroenterol 2014; 20: 10316-10330. https://doi. org/10.3748/wjg.v20.i30.10316

[4] DAMANIA D, ROY HK, SUBRAMANIAN H, WEINBERG DS, REX DK et al. Nanocytology of rectal colonocytes to assess risk of colon cancer based on field cancerization. Cancer Res 2012; 72: 2720-2727. https://doi.org/10.1158/0008-5472. CAN-11-3807

[5] LIEBERMAN D. Progress and challenges in colorectal cancer screening and surveillance. Gastroenterology 2010; 138: 2115-2126. https://doi.org/10.1053/j.gastro.2010.02.006

[6] WUWK,LAWPT,LEECW,CHOCH,FAND etal.MicroRNA in colorectal cancer: from benchtop to bedside. Carcinogenesis 2011; 32: 247-253. https://doi.org/10.1093/carcin/bgq243

[7] KEKU TO, VIDAL A, OLIVER S, HOYO C, HALL IJ et al. Genetic variants in IGF-I, IGF-II, IGFBP-3, and adiponectin genes and colon cancer risk in African Americans and Whites. Cancer Causes Control 2012; 23: 1127-1138. https:// doi.org/10.1007/s10552-012-9981-2

[8] HOPPENER JW, DE PAGTER-HOLTHUIZEN P, GEURTS VAN KESSEL AH, JANSEN M, KITTUR SD et al. The human gene encoding insulin-like growth factor I is located on chromosome 12. Hum Genet 1985; 69: 157-160.

[9] SHIRATSUCHI I, AKAGI Y, KAWAHARA A, KINUGASA T, ROMEO $\mathrm{K}$ et al. Expression of IGF-1 and IGF-1R and their relation to clinicopathological factors in colorectal cancer. Anticancer Res 2011; 31: 2541-2545. 
[10] SOUBRY A1, IL'YASOVA D, SEDJO R, WANG F, BYERS T et al. Increase in circulating levels of IGF-1 and IGF-1/IGFBP-3 molar ratio over a decade is associated with colorectal adenomatous polyps. Int J Cancer 2012; 131: 512-517. https://doi. org/10.1002/ijc.26393

[11] GE W, LI Y, XIANG H, LI H. Lack of association of IGFBP-3 gene polymorphisms with colorectal cancer: evidence from 17,380 subjects. Mol Biol Rep 2014; 41: 2609-2615. https://doi. org/10.1007/s11033-014-3119-4

[12] JIANG B, ZHANG X, DU LL, WANG Y, LIU DB et al. Possible roles of insulin, IGF-1 and IGFBPs in initiation and progression of colorectal cancer. World J Gastroenterol 2014; 20 : 1608-1613. https://doi.org/10.3748/wjg.v20.i6.1608

[13] FEIK E, BAIERL A, HIEGER B, FUHRLINGER G, PENTZ A et al. Association of IGF1 and IGFBP3 polymorphisms with colorectal polyps and colorectal cancer risk. Cancer Causes Control 2010; 21: 91-97. https://doi.org/10.1007/s10552-0099438-4

[14] PHILIPPOU A, MARIDAKI M, PNEUMATICOS S, KOUTSILIERIS M. The complexity of the IGF1 gene splicing, posttranslational modification and bioactivity. Mol Med 2014; 20: 202-214. https://doi.org/10.2119/molmed.2014.00011

[15] CUBBAGE ML, SUWANICHKUL A, POWELL DR. Insulinlike growth factor binding protein-3. Organization of the human chromosomal gene and demonstration of promoter activity. J Biol Chem 1990; 265: 12642-12649.

[16] NATSUIZAKA M, KINUGASA H, KAGAWA S, WHELAN KA, NAGANUMA S et al. IGFBP3 promotes esophageal cancer growth by suppressing oxidative stress in hypoxic tumor microenvironment. Am J Cancer Res 2014; 4: 29-41.

[17] TAYYEM RF, BAWADI HA, SHEHADAH IN, ABU-MWEIS SS, AGRAIB LM et al. Macro- and micronutrients consumption and the risk for colorectal cancer among Jordanians. Nutrients 2015; 7: 1769-1786. https://doi.org/10.3390/nu7031769

[18] TIAN D, KREEGER PK. Analysis of the quantitative balance between insulin-like growth factor (IGF)-1 ligand, receptor, and binding protein levels to predict cell sensitivity and therapeutic efficacy. BMC Syst Biol 2014; 8: 98. https://doi. org/10.1186/s12918-014-0098-y

[19] CAO Y, LINDSTROM S, SCHUMACHER F, STEVENS VL, ALBANES D et al. Insulin-like growth factor pathway genetic polymorphisms, circulating IGF1 and IGFBP3, and prostate cancer survival. J Natl Cancer Inst 2014; 106: dju085. https:// doi.org/10.1093/jnci/dju085

[20] ZHANG Q, GUY K, PAGADALA J, JIANG Y, WALKER RJ et al. Compound $49 \mathrm{~b}$ prevents diabetes-induced apoptosis through increased IGFBP-3 levels. Invest Ophthalmol Vis Sci 2012; 53: 3004-3013. https://doi.org/10.1167/iovs.11-8779

[21] SIMONS CC, SCHOUTEN LJ, GODSCHALK RW, VAN ENGELAND M, VAN DEN BRANDT PA et al. Genetic Variants in the Insulin-like Growth Factor Pathway and Colorectal Cancer Risk in the Netherlands Cohort Study. Sci Rep 2015; 5: 14126. https://doi.org/10.1038/srep14126

[22] XIANG H, LIU L, CHU GD, WEI S, LIU JP et al. Association between two functional polymorphisms of insulin-like growth factor binding protein 3 and colorectal cancer risk in a Chinese population. J Toxicol Environ Health A 2009; 72: 706-711. https://doi.org/10.1080/15287390902841060
[23] PECHLIVANIS S, WAGNER K, CHANG-CLAUDE J, HOFFMEISTER M, BRENNER $H$ et al. Polymorphisms in the insulin like growth factor 1 and IGF binding protein 3 genes and risk of colorectal cancer. Cancer Detect Prev 2007; 31: 408416. https://doi.org/10.1016/j.cdp.2007.10.001

[24] KARIMI K, MAHMOUDI T, KARIMI N, DOLATMORADI $\mathrm{H}$, ARKANI $\mathrm{M}$ et al. Is there an association between variants in candidate insulin pathway genes IGF-I, IGFBP-3, INSR, and IRS2 and risk of colorectal cancer in the Iranian population? Asian Pac J Cancer Prev 2013; 14: 5011-5016.

[25] CHEN H, MANNING AK, DUPUIS J. A method of moments estimator for random effect multivariate meta-analysis. Biometrics 2012; 68: 1278-1284. https://doi.org/10.1111/j.15410420.2012.01761.x

[26] PETERS JL, SUTTON AJ, JONES DR, ABRAMS KR, RUSHTON L. Comparison of two methods to detect publication bias in meta-analysis. JAMA 2006; 295: 676-680. https://doi. org/10.1001/jama.295.6.676

[27] ZINTZARAS E, IOANNIDIS JP. Heterogeneity testing in meta-analysis of genome searches. Genet Epidemiol 2005; 28: 123-137. https://doi.org/10.1002/gepi.20048

[28] HUIZENGA HM, VISSER I, DOLAN CV. Testing overall and moderator effects in random effects meta-regression. Br J Math Stat Psychol 2011; 64: 1-19. https://doi. org/10.1348/000711010X522687

[29] JACKSON D, WHITE IR, RILEY RD. Quantifying the impact of between-study heterogeneity in multivariate meta-analyses. StatMed2012;31:3805-3820.https://doi.org/10.1002/sim.5453

[30] FERRENBERG AM, SWENDSEN RH. New Monte Carlo technique for studying phase transitions. Phys Rev Lett 1988; 61: 2635-2638. https://doi.org/10.1103/PhysRevLett.61.2635

[31] STERNE JA, EGGER M. Funnel plots for detecting bias in meta-analysis: guidelines on choice of axis. J Clin Epidemiol 2001; 54: 1046-1055.

[32] WIKSTROM EA, NAIK S, LODHA N, CAURAUGH JH. Balance capabilities after lateral ankle trauma and intervention: a meta-analysis. Med Sci Sports Exerc 2009; 41: 1287-1295. https://doi.org/10.1249/MSS.0b013e318196cbc6

[33] EGGER M, DAVEY SMITH G, SCHNEIDER M, MINDER C. Bias in meta-analysis detected by a simple, graphical test. BMJ 1997; 315: 629-634.

[34] LE MARCHAND L, KOLONEL LN, HENDERSON BE, WILKENS LR. Association of an exon 1 polymorphism in the IGFBP3 gene with circulating IGFBP-3 levels and colorectal cancer risk: the multiethnic cohort study. Cancer Epidemiol Biomarkers Prev 2005; 14: 1319-1321. https://doi. org/10.1158/1055-9965.EPI-04-0847

[35] MORIMOTO LM, NEWCOMB PA, WHITE E, BIGLER J, POTTER JD. Variation in plasma insulin-like growth factor-1 and insulin-like growth factor binding protein-3: personal and lifestyle factors (United States). Cancer Causes Control 2005; 16: 917-927. https://doi.org/10.1007/s10552005-2702-3

[36] OLLBERDING NJ, CHENG I, WILKENS LR, HENDERSON BE, POLLAK MN et al. Genetic variants, prediagnostic circulating levels of insulin-like growth factors, insulin, and glucose and the risk of colorectal cancer: the Multiethnic Cohort study. Cancer Epidemiol Biomarkers Prev 2012; 21: 810-820. https://doi.org/10.1158/1055-9965.EPI-11-1105 
[37] SAMOWITZ WS, WOLFF RK, MA KN, ANDERSEN K, CAAN B et al. Polymorphisms in insulin-related genes predispose to specific KRAS2 and TP53 mutations in colon cancer. Mutat Res 2006; 595: 117-124. https://doi.org/10.1016/j. mrfmmm.2005.10.014

[38] SLATTERY ML, CURTIN K, WOLFF R, MA KN, SWEENEY C et al. PPARgamma and colon and rectal cancer: associations with specific tumor mutations, aspirin, ibuprofen and insulin-related genes (United States). Cancer Causes Control 2006; 17: 239-249. https://doi.org/10.1007/s10552005-0411-6

[39] WONG HL, DELELLIS K, PROBST-HENSCH N, KOH WP, VAN DEN BERG D et al. A new single nucleotide polymorphism in the insulin-like growth factor I regulatory region associates with colorectal cancer risk in singapore chinese. Cancer Epidemiol Biomarkers Prev 2005; 14: 144-151.

[40] TALEBPOUR AMIRI F, FADAEI FATHABADI F, MAHMOUDI RAD M, PIRYAE A, GHASEMI A et al. The effects of insulin-like growth factor-1 gene therapy and cell transplantation on rat acute wound model. Iran Red Crescent Med J 2014; 16: e16323. https://doi.org/10.5812/ircmj.16323

[41] SCHIAFFINO S, MAMMUCARI C. Regulation of skeletal muscle growth by the IGF1-Akt/PKB pathway: insights from genetic models. Skelet Muscle 2011; 1: 4. https://doi. org/10.1186/2044-5040-1-4
[42] PATEL AV, CHENG I, CANZIAN F, LE MARCHAND L, THUN MJ et al. IGF-1, IGFBP-1, and IGFBP-3 polymorphisms predict circulating IGF levels but not breast cancer risk: findings from the Breast and Prostate Cancer Cohort Consortium (BPC3). PLoS One 2008; 3: e2578. https://doi. org/10.1371/journal.pone.0002578

[43] KAPLAN RC, PETERSEN AK, CHEN MH, TEUMER A, GLAZER NL et al. A genome-wide association study identifies novel loci associated with circulating IGF-I and IGFBP-3. Hum Mol Genet 2011; 20: 1241-1251. https://doi. org/10.1093/hmg/ddq560

[44] PANKAJ J, KUMARI JR, KIM W, LEE SA. Insulin-like Growth Factor-1, IGF-binding Protein-3, C-peptide and Colorectal Cancer: a Case-control Study. Asian Pac J Cancer Prev 2015; 16: 3735-3740.

[45] XIANG H, WANG Y, NIE S. Meta-analysis of the association between insulin-like growth factor binding protein 3 genetic polymorphisms and colorectal cancer susceptibility. PLoS One 2013; 8: e59665. https://doi.org/10.1371/journal. pone. 0059665

[46] SCHUMACHER FR, CHENG I, FREEDMAN ML, MUCCI L, ALLEN NE et al. A comprehensive analysis of common IGF1, IGFBP1 and IGFBP3 genetic variation with prospective IGF-I and IGFBP-3 blood levels and prostate cancer risk among Caucasians. Hum Mol Genet 2010; 19: 3089-3101. https://doi.org/10.1093/hmg/ddq210 


\section{Meta-analysis of the association of IGFBP3 and IGF1 polymorphisms with susceptibility to colorectal cancer}

W. WANG, B. Q. WU, G. B. CHEN*, Y. ZHOU, Z. H. LI, J. L. ZHANG, Y. L. DING, P. ZHANG, J. Q. WANG

\section{Supplemental Material}

A

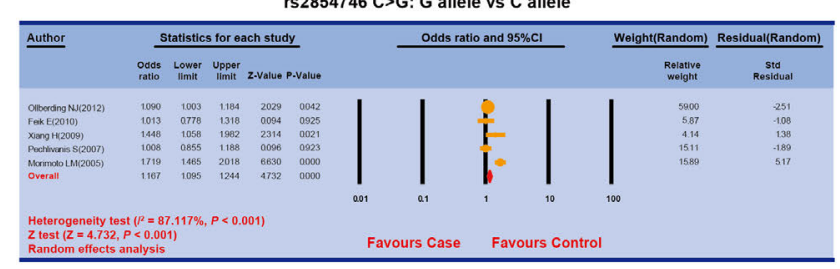

c

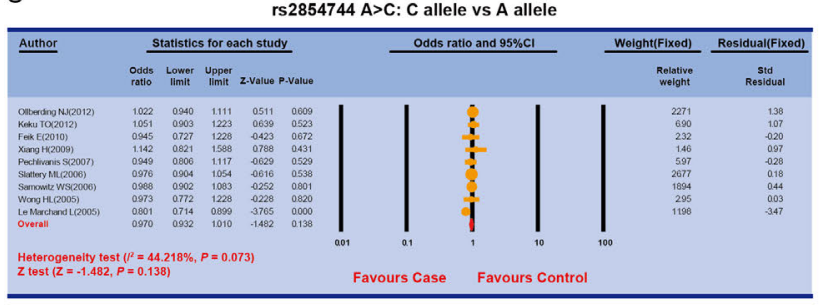

E

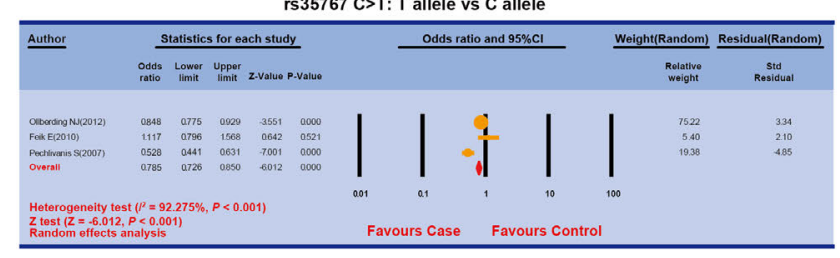

Supplementary Figure 1.

A

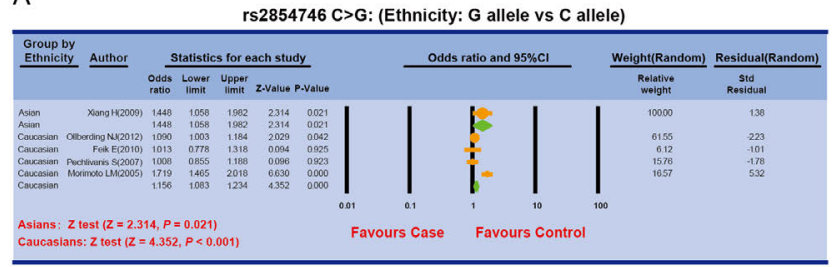

C

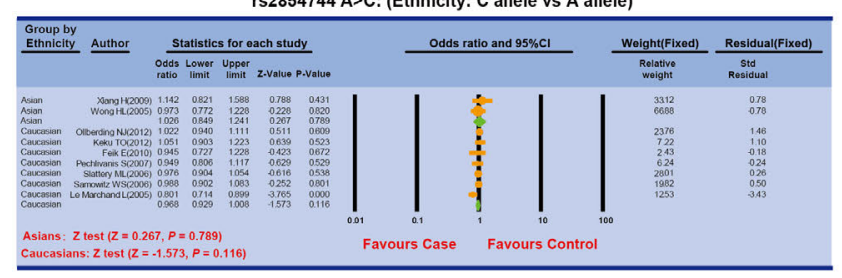

B

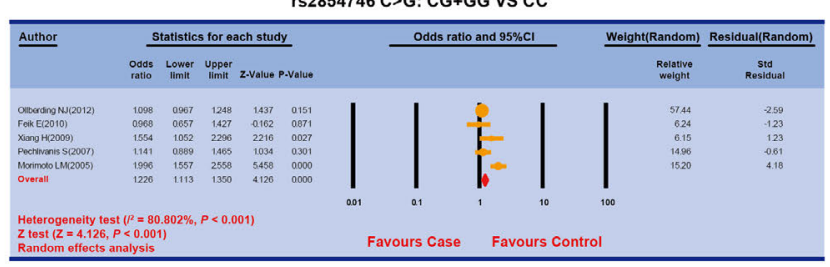

D

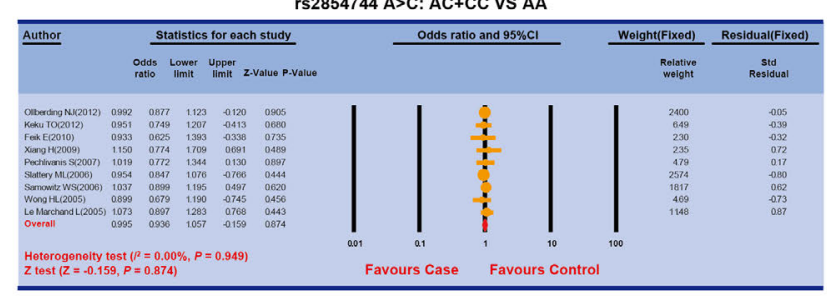

$\mathrm{F}$

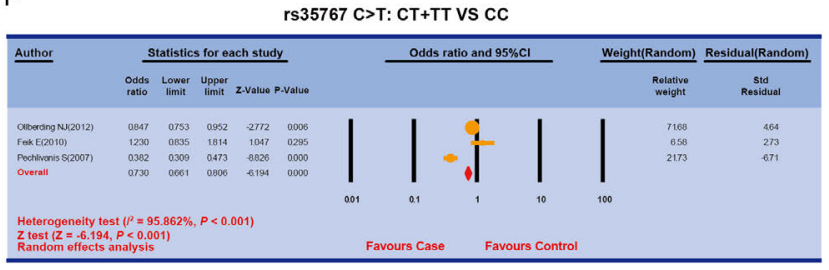

B

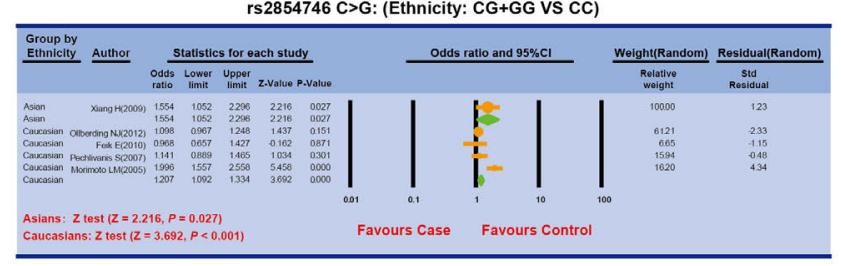

D

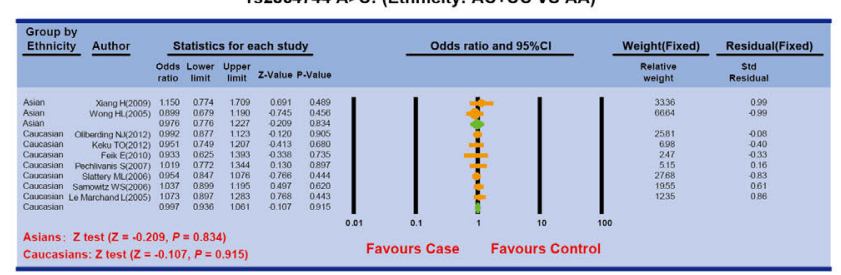

Supplementary Figure 2. 
A

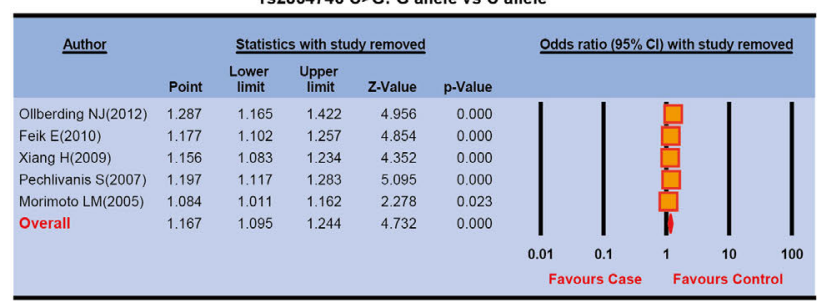

C

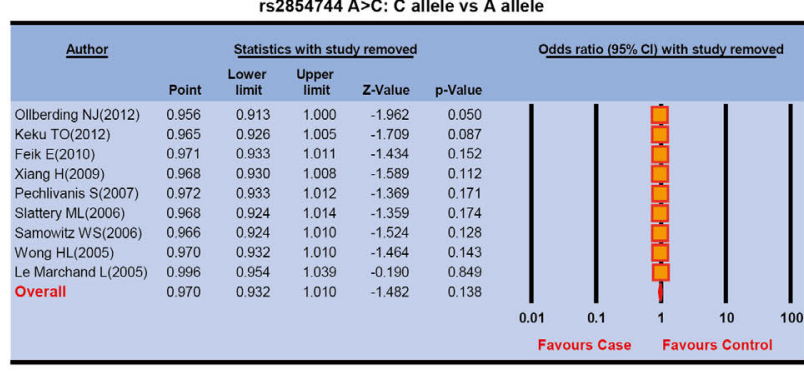

$\mathrm{E}$

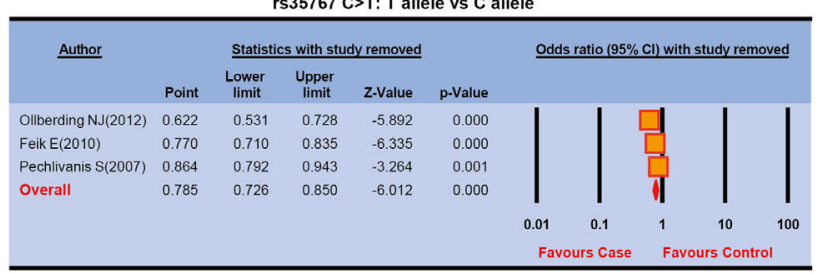

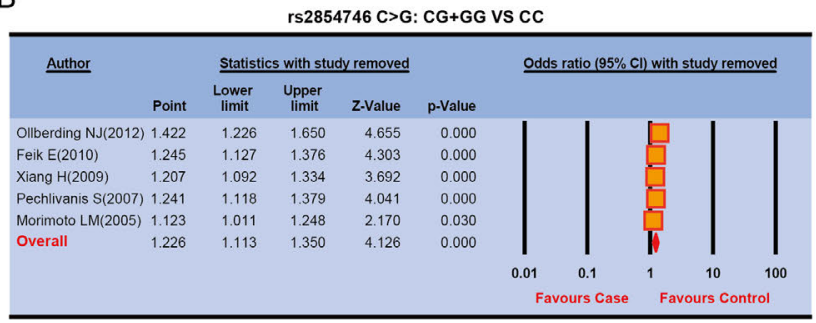

$\mathrm{D}$

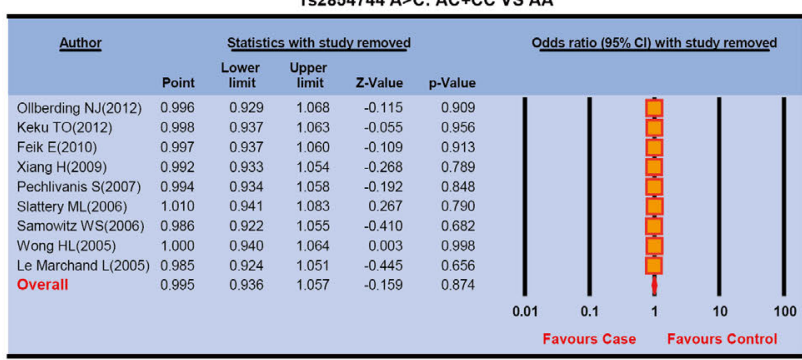

$\mathrm{F}$

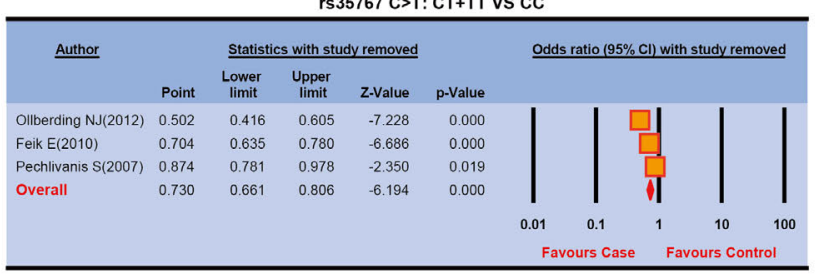

Supplementary Figure 3.

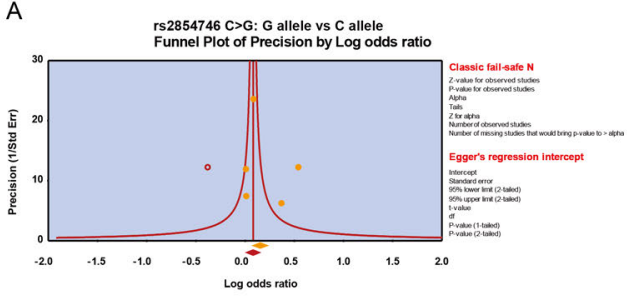

C

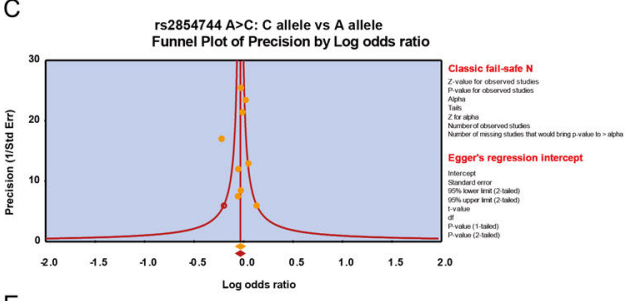

$E$

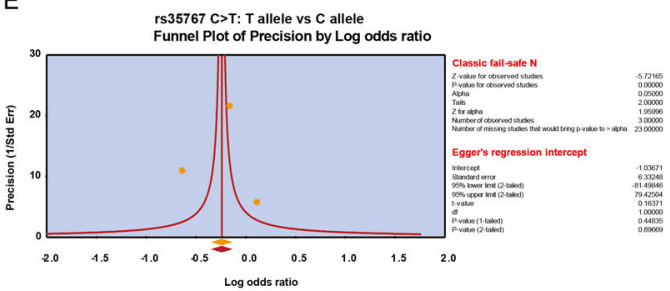

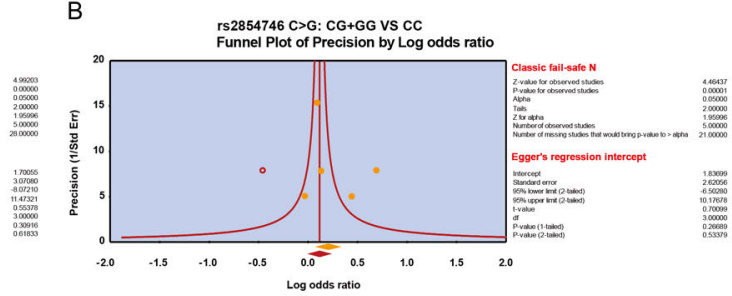

$\mathrm{D}$

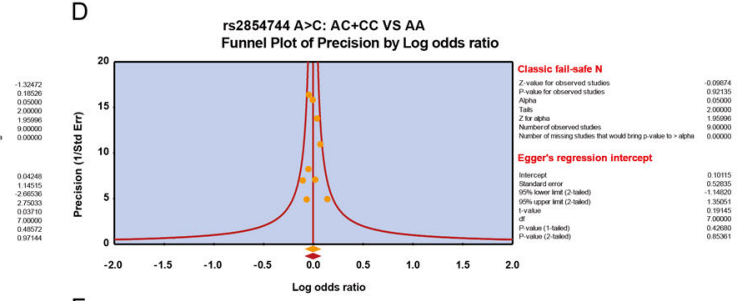

$\mathrm{F}$

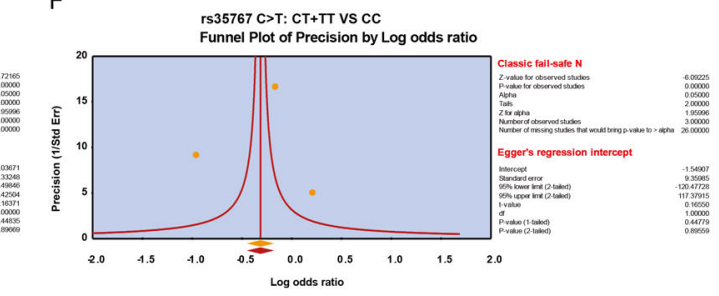

Supplementary Figure 4. 